\title{
Financial Inclusion in Egypt: Does It Affect Banks' Profitability and Liquidity?
}

\author{
Nisreen Mohammed Said Almaleeh \\ Accounting department, Faculty of Commerce \\ Menofia University, Egypt \\ E-mail: nesreen.mohamed@commerce.menofia.edu.eg
}

Received: March 10, 2020

Accepted: April 12, $2020 \quad$ Published: April 16, 2020

doi:10.5296/ifb.v7i1.16865

URL: http://dx.doi.org/10.5296/ifb.v7i1.16865

\begin{abstract}
The purpose of this study is to investigate the association between financial inclusion and levels of profitability and liquidity of Egyptian banks. Two hypotheses are tested; the first is about whether financial inclusion has an impact on the Egyptian banks' profitability, and the second is about whether financial inclusion has an impact on the Egyptian banks' liquidity. Data of Egyptian banks for the period from 2012 to September 2018 are used to test the hypotheses of the study. Financial inclusion is measured by the access and usage measures derived from the G20 summit "Global partnership for Financial Inclusion", profitability and liquidity are measured by multiple agreed-upon measures. The study which employed various regression models reveals that 53\% of the variance in the Egyptian banks' profitability can be explained by the variance in the financial inclusion measures, and that the various measures of banks' liquidity are significantly affected by financial inclusion.
\end{abstract}

Keywords: Financial inclusion, emerging economies, Egyptian banks, Profitability, Liquidity. 


\section{Introduction}

The primary purpose of the banking system is to encourage institutions and individuals to save and then transfer those savings to other institutions and individuals planning to invest in new projects, which causes the economy to grow, creates new jobs, and raises the living standards (Rose \& Hudgins, 2005) But the banking system does much more than merely transferring savings into investments; it facilitates the payment and settlements systems, supports the smooth transfer of goods and services, helps to develop new industries, and ensures productive investment of capital in order to eventually stimulate the economic growth (Arif \& Anees, 2012). As a result to these facts, the strength of the banking system can be considered as an essential requirement to ensure the economic stability and growth in any country.

Despite this fact, some population groups are still not adequately covered by the formal financial system services in all countries regardless of their income levels. Although the world economy has achieved remarkable rapid development lately, severe financial access gaps still exist; more than $50 \%$ of the working-age population around the world does not have access to formal financial services which amounts to 2.5 billion adults, the majority of them around 2.2 billion- lives in Africa, Asia, Latin America, and Middle East countries (Shankar, 2013). This fact is confirmed by the World Bank's data as around $50 \%$ of the adult population in the world does not have accounts at formal financial institutions. This situation is even worse in developing countries; for example, only $24 \%$ of African population has accounts at formal financial institutions compared to $84 \%$ in high income countries (Abifarin \& Bello, 2015).

Focusing on the Egyptian banking sector, it has undergone a major reform program during the last decade, Egypt has launched the Financial Sector Reform Program (FSRP) in September 2004 with a main objective of enhancing the soundness of the financial sector and promoting the evolution of an efficient, private-led financial system that serves Egypt's development and growth objectives (World Bank, 2010). This reform program was undertaken through two phases (2004-2008) and (2009-2012) and resulted in a rapid and steady growth in the Egyptian banking sector which has grown in comparison with the size of the economy from $91 \%$ in 2013 to $122 \%$ in 2016. (EMNES, 2010)

\section{Conceptual Framework}

Financial inclusion has been considered as one of the most important concepts which recently attracted the attention of international organizations and central banks all over the world. It refers to the access of both individuals and businesses to the products and services presented by formal financial institutions such as transactions, payments, savings, credit and insurance, at a reasonable cost and in a sustainable mode. (Alex bank, 2017)

Recently, financial inclusion has been considered a crucial determinant of economic growth; individuals that are included in the financial system are able to start businesses and invest their saved funds. This situation contributes to the reduction of poverty and enhances economic growth (Bruhn \& Love, 2014). Financial inclusion can also help in maintaining 
financial stability as it provides individuals with the means to save for the future in a safe place. Besides, a high usage rate of bank deposits contributes to a more stable deposit base for banks which will protect banks through troubled times (Han \& Melecky, 2013).

In the light of the above, official financial authorities such as central banks encourage banks and other financial institutions to offer financial services that cover the needs of both individuals and small and medium enterprises (SMEs) through issuing different policies and regulations (Shihadeh et. al., 2018). Moreover, international institutions such as the World Bank, Alliance for financial inclusion (AFI) and Group 20 (G20) are trying to achieve objectives of enhancing economic growth, reducing the rate of unemployment and reinforcing economic stability. These objectives can possibly be achieved through facilitating the access of individuals and SMEs to financial sources (Beck \& Demirguc-Kunt, 2006; Honohan, 2008; Swamy, 2014) which is the primary target of financial inclusion.

Considering the Egyptian banking industry in particular, Egypt suffers from high levels of financial exclusion, where only about $14 \%$ of adults had bank accounts in 2014 , and this percentage reached 33\% in 2017 after applying several measures to encourage account penetration for Egyptian adults (Alex Bank, 2017). This situation is significantly due to the presence of a sizable informal sector along with high poverty and unemployment rates. In addition to that, Egypt is considered mainly as a cash-based economy where cash transactions dominate the majority of its activities.

In the light of the above, Financial inclusion has been set as a priority in the Egyptian banking system the last years. In July 2017, Egypt was chosen as a model country in the new Financial Inclusion Global Initiative launched by the World Bank Group. This initiative aims to support access to financial services to the unbanked and the underbanked. It also aims to develop policy recommendations in digital finance (Alex Bank, 2017).

The above-mentioned measures must be accompanied by sound liquidity management practices, in addition to ensuring they will not endanger banks' profitability in order to enable banks to achieve financial inclusion objectives. And this concern is what this study is trying to explore.

\section{Literature Review}

In recent years, there has been an increasing amount of literature on financial inclusion. Numerous studies have discussed and examined the effect of financial inclusion on the performance of small and medium enterprises SMEs (e.g. Beck \& Demirguc-Kunt, 2006; Ifeakachukwu \& Olasunkanmi, 2013; Ben Naceur, 2014). Another group of studies investigated the current state of financial inclusion in certain countries, and its effect on the country’s economic welfare (e.g. Kumar, 2013; Fungáčová \& Weill, 2015; Chikalipah, 2017). Both groups covered the demand side of financial inclusion, only a limited number of studies have explored the effects of financial inclusion on the performance of banks i.e. the supply side of financial inclusion.

As this study is trying to explore the effect of financial inclusion on banks' profitability and liquidity, the following presentation of literature review will focus on the available limited 
number of studies that have investigated the relationship between financial inclusion and banks' liquidity and profitability:

\subsection{Literature Review of the Relationship Between Financial Inclusion and Bank's Profitability}

A considerable amount of literature has tied increasing the number of Automated teller machines (ATMs) and the profitability of banks. (Humphrey, 1994) explored the effect of the increased use of ATMs on banks' performance, the study concluded that the costs accompanied by expanding the usage of ATMs are slightly higher, but this negative effect can be offset by the increased revenues raised by ATMs which are sufficient to increase the banks' profits. This is due to the fact that profits are marginally higher with the usage of ATMs. On the other hand, the study concluded that the users of the banks' services have benefited more from using ATMs than the banks have. Similarly, (Jegede, 2014) has concluded that the expansion in using ATMs will improve the performance of Nigerian banks, contribute to the effectiveness of the banking sector, and enhance the opportunities of bank growth.

Another group of studies investigated the relationship between the expansion of issuing credit cards and banks' performance. (Alfonse \& Florence, 2012) examined the impact of credit cards on the performance on commercial banks in Kenya and concluded that expanding the credit cards number is going to improve the performance of Kenyan banks. In the same context, (Muiruri \& Ngari, 2014) indicated that banks are motivated to pursue various financial innovations by numerous interests and that credit cards have been widely adopted by banks to increase income, profits, and to mitigate credit and liquidity risks. the study concluded that banks employ internet banking in order to improve accuracy and efficiency, and to increase the speed and reliability of the banking services, which would eventually improve the banks' profitability.

Other studies combined more than financial inclusion indicator and explored their effect of banks' performance, (Akhisar et. al., 2015) investigated the effects of electronic-based banking services on the bank's profitability which was measured by return on assets ROA and return on equity ROE. The findings indicated that all the banking services that were considered; credit cards, debit cards, and the ratio of the number of ATMs to the number of branches affect profitability in a positive way. It also concluded that the ratio of the number of ATMs to the number of branches has a higher degree of positive effect on bank's profitability than other variables, and this is due to the fact that ATM transactions reduce operational costs compared to branch office based transactions.

This view has been supported by (Sansone \& Formisano, 2016) which analyzed the relationship between marketing innovation and the performance of a banking enterprise. The variables employed to estimate marketing innovation consisted of total number of services offered to customers and total number of online services. The performance of the bank was measured by the change in net income, the change in interest income, and the change in operating income. They concluded that marketing innovation enable banks to overcome economic obstacles, and enhance performance indicators. 
In the same vein, (Shihadeh et. al., 2018) Investigated the relationship between financial inclusion and banks' performance. Performance was measured by gross income and ROA, while six different measures of financial inclusion were employed, these measures are credits for small and medium enterprises, number of ATMs, number of ATM services, number of credit cards, and new services, they concluded that new services as e determinant of bank innovation has a significant effect on the performance of banks. Other financial inclusion indicators had insignificant effect on performance when considered separately. In spite of this, when analyzed aggregately, financial inclusion indicators had a positive effect on the performance of banks.

\subsection{Literature Review of the Relationship Between Financial Inclusion and Bank's Liquidity}

Most studies in the field of financial inclusion have only focused on its effect on profitability of banks. There have been a limited number of attempts of relating financial inclusion and banks' liquidity and financial stability. In addition to that, there is lack of studies that were carried out in the Middle East and North Africa (MENA) region such as Egypt.

One study by Hannig \& Jansen (2010) concluded that low-income groups are relatively impregnable to economic cycles to the extent that including them in the financial sector will tend to increase the stability of deposit and loan bases resulting in lower liquidity risk in the financial sector. They introduced evidence that suggested that financial institutions serving more low-income groups tend to deal with crises better and contribute to sustaining economic activity.

In his analysis of the relationship between financial inclusion and financial stability, Prasad (2010) observed that with the absence of adequate access to credit by small and medium size enterprises (SMEs) and small-scale entrepreneurs, a negative effect on the overall economic stability would take place, this is due to the fact that these enterprises tend to be more labor intensive and are a major factor of employment growth. In the same vein, Morgan \& Pontines (2014) concluded that a greater level of financial inclusion affects the financial stability positively; they specifically found evidence that an increased level of lending SMEs aids financial stability, mainly by a reduction in non-performing loans (NPLs) and a probability of default by financial institutions.

In contrast to these studies, another investigation suggested that financial inclusion can have a mixed effect on banks' liquidity. As for the positive affect, Khan (2011) suggested that increased lending to smaller firms and households leads to a greater degree of diversification of bank assets which will reduce the overall riskiness of a bank's loan portfolio resulting in reducing the relative size of any single borrower in the overall portfolio thus reducing its volatility. Besides, as the number of small-scale savers increase, both the size and the stability of the deposit base will increase, resulting in less reliance on non-core financing. As for the negative effect, He concluded that the attempt of banks to expand their pool of borrowers will result in sacrificing some lending standards, which was a major contributor of initiating the financial crisis in the United States. Also, if the expansion in lending SMEs is not properly regulated, this could weaken the overall effectiveness of regulation in the economy and increase financial system's risks. 


\section{Hypotheses Development}

So far, financial inclusion is still a new comer in the accounting research area with its implications and consequences not yet enough investigated nor its effects on the accounting profession well discussed and agreed upon. In addition to that, financial inclusion in Egypt is not a well-covered area of research despite the fact that Egypt suffers from unemployment problems that reached $12 \%$ in 2017 and that it is endangered by several political and economic instabilities, the situation that suggests that improving the Egyptian financial sector will lead to better levels of economic development. (CGAP, 2010)

In their attempts to reach higher levels of financial inclusion, banks invest more resources in developing their existing services and innovating new services that are designed to fulfill customer needs and achieve suitable return to enhance bank's performance. In this context, banks expand their network of branches and ATMs to increase their customers' reach, attract deposits, and facilitate offering services, resulting in increasing capital expenditures to the extent that decreases banks' profits if they are not able to achieve enough earnings.

What we know about the relationship between financial inclusion and banks' profitability is largely based upon studies the investigated how expansion in ATM networks and credit card issuance could affect banks' earnings. (Frame \& White, 2014; Beck et. al., 2014; Monyoncho, 2015) demonstrated that ATMs, ATM cards, debit cards and credit cards improve access to finance and financial inclusion as they tend to cover customer needs more efficiently, but they have related costs such as machines, technology, research and development, rent, advertising, security, training, and maintenance costs.

These services do not expand banks' direct revenues as they are usually offered with little or no fees. As a result, they may impose a burden on the banks' financial results on the short term. This discussion postulates the following hypothesis:

H1: financial inclusion has an impact on the Egyptian banks' profitability.

On the other hand, the relationship between financial inclusion and banks' liquidity is still an ambiguous area of research; SMEs generally suffer low credit rates especially in the MENA region as credits to SMEs do not exceed $10 \%$ of total credits in the MENA region (Shihadeh et. al., 2018). The main reason for this low percentage is direct risks associated with the expansion in lending SMEs. By innovating services and reforming their operations, banks can better address the needs of SMEs and be able to lend them more which will put banks in a situation of either endangering the banks' liquidity levels as the probability of inability to repay the loans given to SMEs is higher (Khan, 2011), or attracting more SMEs deposits which will improve liquidity on the long term (Ben Naceur, 2014).based on this discussion, the following hypothesis stems:

H2: financial inclusion has an impact on the Egyptian banks' liquidity.

\section{Data}

The current study tries to investigate the impact of financial inclusion on the Egyptian banks' profitability and liquidity, this section is going to discuss how each of these variables was 
measured:

\subsection{Measurement of Financial Inclusion}

According to the G20 summit held in Los Cabos in 2012, financial inclusion can be measured using the following three measures:

Access: refers to the ability to use the available financial services and products introduced by formal financial institutions. Using access as a measure of financial inclusion requires the analysis of potential barriers to opening and using bank accounts such as costs and physical proximity of service points including branches and ATMs. One basic proxy for access can be calculated through counting the number of open accounts across financial institutions and then calculating the proportion of population which have bank accounts.

Quality: refers to the relevance of the financial products or services to the needs of the customer. Quality involves the experience of the customer demonstrated in attitudes and opinions toward the products and services available to them.

Usage: beyond the basic adoption of the services introduced by financial institutions, usage focuses more on the continuation and depth of financial services and products usage; therefore, measuring it requires more details about the regularity, frequency, and duration of financial services usage overtime.

Each of the previous measures encompasses several factors used to measure financial inclusion levels on the demand side. The current study investigates financial inclusion from the supply side and because it is an applied study, data about customers' opinions and attitudes are not attainable except by using surveys; therefore, financial inclusion is going to be measured using access and usage measures only.

Data about access and usage was obtained from the reports published by the Central Bank of Egypt (CBE) which aggregates the financial soundness indicators of the Egyptian banking sector in the period from 2012 till September 2018. The indicators that were used to assess financial inclusion in Egypt are presented in the next figure:

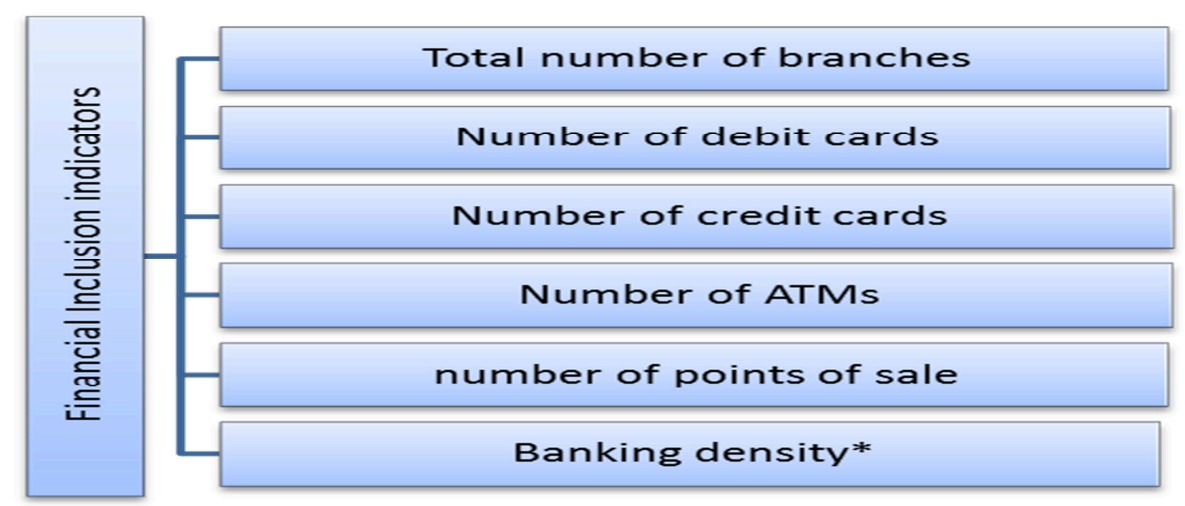

Figure 1. financial inclusion indicators

* Measured by population in thousands per banking unit 


\subsection{Measurement of Banks' Profitability}

The measures of banks' profitability include return on assets (ROA) or return on average assets (ROAA) which reflects the ability of the management to generate profits from the assets held by the bank. They also include return on equity (ROE) or return on average equity (ROAE) which indicates the return which shareholders get on their equity.

The net interest margin (NIM) is also greatly employed by a group of previous studies to evaluate the bank's profitability.net interest margin (NIM) focuses on the traditional borrowing and lending operations performed by banks by measuring the gap between what a bank pays to its savers and what it receives from its borrowers.

Three variables were employed to measure the profitability of the Egyptian banks in the period from 2012 to September 2018; these measures were also extracted from the financial soundness indicators of the Egyptian banking sector reports issued by the CBE and they are presented in the next figure:

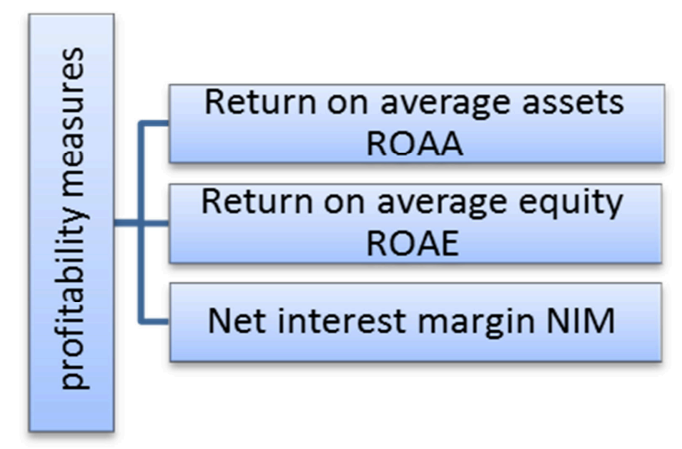

Figure 2. profitability measures

\subsection{Measurement of Banks' Liquidity}

The current ratio and the working capital are widely used as measures of liquidity, the current ratio measures the relationship between total current assets and total current liabilities, the higher the ratio, the more liquid the bank is considered to be. On the other hand, working capital is a measure of the amount of funds that remains available after the sale of current assets and payment of current liabilities. It is expressed in absolute amount rather than a percentage.

Other liquidity ratios were used to assess the liquidity positions of banks and other financial institutions. Several studies used the liquid assets to total assets ratio, the liquid assets to deposits ratio and the liquid assets to customer and short term funding .On the other hand, loans to total assets ratio and net loans to customer and short term funding ratio were employed by various studies to evaluate banks' liquidity risk.

The five measures that were used to evaluate liquidity positions of Egyptian banks in the 
period from 2012 to September 2018 were extracted from the above mentioned reports issued by $\mathrm{CBE}$, and they are presented in the next figure:

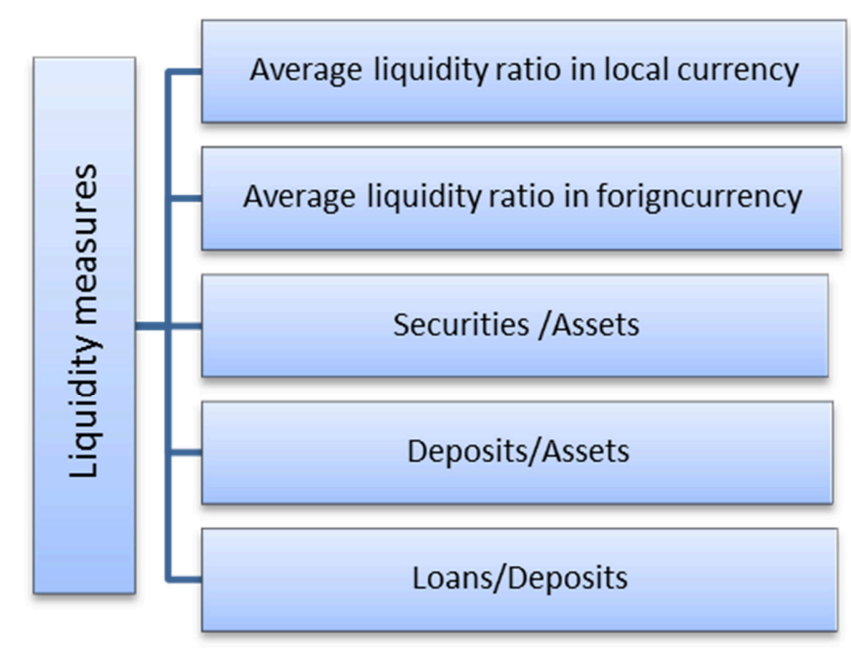

Figure 3. Liquidity measures

\section{Methodology}

The study employs an empirical method based on data obtained from the reports published by the Central Bank of Egypt CBE. It examines the effect of financial inclusion on both Egyptian banks' profitability and liquidity. The following models are adopted to assess the effect of financial inclusion on Egyptian banks' profitability and liquidity:

$$
\begin{aligned}
& \mathrm{ROAA}=\beta 0+\beta 1 \mathrm{NOB}+\beta 2 \mathrm{NODC}+\beta 3 \mathrm{NOCC}+\beta 4 \mathrm{NOATM}+\beta 5 \mathrm{NOPOS}+\beta 6 \mathrm{BD}+\varepsilon \mathrm{i} \\
& \mathrm{ROAE}=\beta 0+\beta 1 \mathrm{NOB}+\beta 2 \mathrm{NODC}+\beta 3 \mathrm{NOCC}+\beta 4 \mathrm{NOATM}+\beta 5 \mathrm{NOPOS}+\beta 6 \mathrm{BD}+\varepsilon \mathrm{i} \\
& \mathrm{NIM}=\beta 0+\beta 1 \mathrm{NOB}+\beta 2 \mathrm{NODC}+\beta 3 \mathrm{NOCC}+\beta 4 \mathrm{NOATM}+\beta 5 \mathrm{NOPOS}+\beta 6 \mathrm{BD}+\varepsilon \mathrm{i} \\
& \mathrm{ALRLC}=\beta 0+\beta 1 \mathrm{NOB}+\beta 2 \mathrm{NODC}+\beta 3 \mathrm{NOCC}+\beta 4 \mathrm{NOATM}+\beta 5 \mathrm{NOPOS}+\beta 6 \mathrm{BD}+\varepsilon \mathrm{i} \\
& \mathrm{ALRFC}=\beta 0+\beta 1 \mathrm{NOB}+\beta 2 \mathrm{NODC}+\beta 3 \mathrm{NOCC}+\beta 4 \mathrm{NOATM}+\beta 5 \mathrm{NOPOS}+\beta 6 \mathrm{BD}+\varepsilon \mathrm{i} \\
& \mathrm{S} / \mathrm{A}=\beta 0+\beta 1 \mathrm{NOB}+\beta 2 \mathrm{NODC}+\beta 3 \mathrm{NOCC}+\beta 4 \mathrm{NOATM}+\beta 5 \mathrm{NOPOS}+\beta 6 \mathrm{BD}+\varepsilon \mathrm{i} \\
& \mathrm{D} / \mathrm{A}=\beta 0+\beta 1 \mathrm{NOB}+\beta 2 \mathrm{NODC}+\beta 3 \mathrm{NOCC}+\beta 4 \mathrm{NOATM}+\beta 5 \mathrm{NOPOS}+\beta 6 \mathrm{BD}+\varepsilon \mathrm{i} \\
& \mathrm{L} / \mathrm{D}=\beta 0+\beta 1 \mathrm{NOB}+\beta 2 \mathrm{NODC}+\beta 3 \mathrm{NOCC}+\beta 4 \mathrm{NOATM}+\beta 5 \mathrm{NOPOS}+\beta 6 \mathrm{BD}+\varepsilon \mathrm{i}
\end{aligned}
$$

Where ROAA refers to return on average assets, $\beta 0$ : constant intercept; NOB: number of branches; NODC: number of debit cards; NOCC: number of credit cards; NOATM: number of ATMs; NOPOS: number of points of sale; BD: banking density; ci: error term. ROAE: Return on average equity; NIM: net interest margin; ALRLC: Average liquidity ratio in local currency; ALRFC: average liquidity ratio in foreign currency; S/A: securities/assets; D/A: deposits/assets; L/D: loans/deposits. 


\section{Results}

This section presents the descriptive statistics, correlation coefficients, and the results of regression analysis. Data management and analysis were performed using SPSS 22. Table 1 shows the descriptive statistics that were generated for all dependent and independent variables including the mean, standard deviation, minimum and maximum observations.

Table 1. Descriptive statistics

\begin{tabular}{lllll}
\hline Variables & Mean & Standard deviation & Min & Max \\
\hline Number of branches & 3912 & 182 & 3610 & 4177 \\
Number of debit cards & 14959070 & 1735842 & 11284042 & 17562134 \\
Number of credit cards & 6101661 & 9653167 & 1798968 & 42016937 \\
Number of ATMs & 9293 & 2051 & 5489 & 12143 \\
Number of points of sale & 61478 & 9791 & 40046 & 75603 \\
Banking density & 23.18 & .2167 & 22.7 & 23.7 \\
Return on average assets & 1.54 & .35 & 1.0 & 2.0 \\
Return on average equity & 23.24 & 6.02 & 13.9 & 30.9 \\
Net interest margin & 4.05 & .4 & 3.5 & 4.6 \\
Liquidity ratio in local currency & 52.44 & 8.6 & 40.3 & 63.1 \\
Liquidity ratio in foreign currency & 61.74 & 8.39 & 48.9 & 74.8 \\
Securities/Assets & 18.6 & 4.31 & 12.8 & 24.3 \\
Deposits/Assets & 74.14 & 6.22 & 67.7 & 84.6 \\
Loans/Deposits & 44.74 & 2.39 & 40.8 & 48.1 \\
\hline
\end{tabular}

Table 1 shows that there is a great difference between the minimum and the maximum values of the measures of financial inclusion, it also shows high values of standard deviation for all these measures, this observation primarily indicates that there is considerable growth in rendering financial services by banks to Egyptians in the study period which extends from 2012 to September 2018 which emphasizes that Egypt is going forward at a steady pace in implementing the financial inclusion plan in line with the financial inclusion initiative launched by the World Bank Group. In spite of the growth in number of branches in Egypt in the study period, banking density variable shows a little amount of growth which can be attributed to the enormous growth in the size of population in this period.

Looking at profitability measures, both return on average assets and net interest margin do not show great difference between minimum and maximum values, they also show little values of standard deviation which indicates an apparent level of stability in the study period. In contradiction with this result, return on average equity shows a higher level of fluctuation between its minimum and maximum values showing a higher-than- average growth as a profitability measure in the study period.

As for liquidity measures, their standard deviation values are ranging around the same value 
with a slight difference between their minimum and maximum values, this indication suggests that the liquidity positions of Egyptian banks are characterized by being stable in the period of 2012 to September 2018.

Table 2. Correlation between financial inclusion indicators and banks' profitability measures

\begin{tabular}{llll}
\hline & $R O A A$ & $R O A E$ & $N I M$ \\
\hline NOB & $.649 * *$ & $.609 * *$ & $.531^{*}$ \\
NODC & $.575^{*}$ & $.501 *$ & .448 \\
NOCC & .077 & .032 & .004 \\
NOATM & $.682^{* *}$ & $.647^{* *}$ & $.563^{*}$ \\
NOPOS & $.699 * *$ & $.664^{* *}$ & $.563^{*}$ \\
BD & $.663^{* *}$ & $.709 * *$ & $.591^{*}$ \\
\hline
\end{tabular}

* Correlation is significant at the 0.05 level

** Correlation is significant at the 0.01 level

Table 2 presents the correlation coefficients among the indicators of financial inclusion and the measures of banks' profitability. Correlation coefficients presented in table 3 shows that most of the financial inclusion indicators are significantly positively correlated with measures of banks' profitability except for the NOCC "number of credit cards" which shows low correlation coefficients, but they remain positive. Table 2 initially suggests that financial inclusion has a strong positive relationship with the Egyptian banks' profitability.

Table 3. Correlation between financial inclusion indicators and banks' liquidity measures

\begin{tabular}{llllll}
\hline & $A L R L C$ & $A L R F C$ & $S / A$ & $D / A$ & $L / D$ \\
\hline NOB & $-.930^{* *}$ & $.789^{* *}$ & $-.906^{* *}$ & $-.899^{* *}$ & .347 \\
NODC & -.394 & .159 & -.340 & -.430 & -.160 \\
NOCC & -.414 & .141 & -.453 & -.336 & .172 \\
NOATM & $-.903^{* *}$ & $.753^{* *}$ & $-.876^{* *}$ & $-.917^{* *}$ & .337 \\
NOPOS & -.816 & $.641^{* *}$ & $-.777^{* *}$ & $-.860^{* *}$ & .262 \\
BD & -.349 & .325 & -.327 & $-.629 * *$ & .254 \\
\hline
\end{tabular}

* Correlation is significant at the 0.05 level

** Correlation is significant at the 0.01 level

Table 3 presents the correlation coefficients among financial inclusion indicators and banks' liquidity measures. It shows that most of financial inclusion indicators are significantly correlated to liquidity measures; some of them are significantly negatively correlated with most of liquidity measures such as NOB "number of branches", NOATM "number of ATMs", and NOPOS "number of points of sale", while other financial inclusion indicators are not 
significantly related to liquidity measures such as NODC "number of debit cards", NOCC "number of credit cards", and BD "banking density". In addition to that, the L/D "loans/deposits" measure of liquidity is not significantly related to any of the financial inclusion indicators. Taken together, table 3 initially suggests that there is a negative relationship between financial inclusion and the liquidity levels of Egyptian banks.

Turning now to the regression analysis, number of credit cards variable NOCC was removed from the three models that predict the effect of financial inclusion indicators on the banks' profitability measures as there is no significant relationship between it and any of the banks' profitability measures. Also, number of debit cards NODC variable was removed from the model that predict the effect of financial inclusion indicators on the net interest margin NIM as there is no significant relationship between them. The revised regression models that are tested are:

$$
\begin{aligned}
& \mathrm{ROAA}=\beta 0+\beta 1 \mathrm{NOB}+\beta 2 \mathrm{NODC}+\beta 3 \mathrm{NOATM}+\beta 4 \mathrm{NOPOS}+\beta 5 \mathrm{BD}+\varepsilon \mathrm{i} \\
& \mathrm{ROAE}=\beta 0+\beta 1 \mathrm{NOB}+\beta 2 \mathrm{NODC}+\beta 3 \mathrm{NOATM}+\beta 4 \mathrm{NOPOS}+\beta 5 \mathrm{BD}+\varepsilon \mathrm{i} \\
& \mathrm{NIM}=\beta 0+\beta 1 \mathrm{NOB}+\beta 2 \mathrm{NOATM}+\beta 3 \mathrm{NOPOS}+\beta 4 \mathrm{BD}+\varepsilon \mathrm{i}
\end{aligned}
$$

As for the models that predict the effect of financial inclusion indicators on the banks' liquidity measures, both number of debit cards NODC and number of credit cards NOCC variables were removed because they do not have significant relationship with any of the banks' liquidity measures, In Addition to that, banking density BD was removed from all the models except the deposit/assets $\mathrm{D} / \mathrm{A}$ model in which it shows a significant relation. Moreover, the model that predict the effect of financial inclusion indicators on the loans/deposits variable L/D was completely removed (was not tested). This is because it has not any significant relationship with any of the financial inclusion indicators. The revised regression models that are tested are:

$$
\begin{aligned}
& \text { ALRLC }=\beta 0+\beta 1 \mathrm{NOB}+\beta 2 \mathrm{NOATM}+\beta 3 \mathrm{NOPOS}+\varepsilon \mathrm{i} \\
& \mathrm{ALRFC}=\beta 0+\beta 1 \mathrm{NOB}+\beta 2 \mathrm{NOATM}+\beta 3 \mathrm{NOPOS}+\varepsilon \mathrm{i} \\
& \mathrm{S} / \mathrm{A}=\beta 0+\beta 1 \mathrm{NOB}+\beta 2 \mathrm{NOATM}+\beta 3 \mathrm{NOPOS}+\varepsilon \mathrm{i} \\
& \mathrm{D} / \mathrm{A}=\beta 0+\beta 1 \mathrm{NOB}+\beta 2 \mathrm{NOATM}+\beta 3 \mathrm{NOPOS}+\beta 4 \mathrm{BD}+\varepsilon \mathrm{i}
\end{aligned}
$$


Table 4 Results of banks' profitability regression models

\begin{tabular}{llll}
\hline & ROAA & ROAE & NIM \\
\hline Constant & -40.379 & -725.3 & -9.535 \\
NOB & .002 & .026 & -.002 \\
NODC & 1.58 & 2.414 & \\
NOATM & .00 & .006 & .001 \\
NOPOS & .00 & -.002 & -.523 \\
BD & 1.52 & 29.35 & .922 \\
Model sig. & .022 & .022 & .133 \\
Adj. $R 2$ & .534 & .534 & .246 \\
\hline
\end{tabular}

Table 4 presents the results obtained from the linear regression analysis performed using SPSS, for both the first dependent variable; return on average assets ROAA, and the second dependent variable; return on average equity ROAE, the regression model results show a significant value of .022 which is less than .05 which means that the independent variables are able to account for a significant amount of variance in the dependent variable. In addition to that, the value of adjusted $\mathrm{R}$ squared for both dependent variables is .534 which means that $53 \%$ of variance in the dependent variables is explained by the independent variables.

Interestingly, the coefficients of the independent variables do not show significant results, this can be due to multicollinearity condition where an independent variable is correlated with other independent variables which can create problems in interpreting the coefficients of the variables; this is because several variables provide duplicate information. (Render et. al., 2017). Although several sets of regression coefficients of the variables that are related would yield exactly the same results making the individual interpretation of these variables questionable, the model itself is still good for prediction purposes, and the overall $\mathrm{F}$ test is still valid, but the hypothesis tests related to individual coefficients are not.

Accordingly, none of the financial inclusion indicators offers significant amount of unique variance in explaining the dependent variables; profitability measures as a result of the existence of correlation between the independent variables themselves, but taken together, they affect the dependent variables significantly.

For the third dependent variable; net interest margin NIM, the model is found to be insignificant with a low value of adjusted $\mathrm{R}$ squared .246. This shows that there is no significant effect of financial inclusion indicators on the net interest margin of Egyptian banks.

Overall, the first hypothesis of this study "financial inclusion has an impact on the Egyptian banks' profitability" can be partially accepted. 


\section{Macrothink}

Table 5. Results of banks' liquidity regression models

\begin{tabular}{lllll}
\hline & ALRLC & ALRFC & S/A & D/A \\
\hline Constant & 215.565 & -44.357 & 721.719 & 58.3 \\
NOB & -.048 & .035 & -.016 & .058 \\
NOATM & -.005 & .008 & -.004 & -.014 \\
NOPOS & .001 & -.002 & .001 & .001 \\
BD & & & & -7.165 \\
Model sig. & .000 & .000 & .000 & .000 \\
Adj. R2 & .914 & .732 & 0908 & .927 \\
\hline
\end{tabular}

The results obtained from the analysis of the effect of financial inclusion indicators on the Egyptian banks' liquidity measures are presented in table 5. This table shows that the results of the four models are significant with a model significance value of .000 , and high values of adjusted $\mathrm{R}$ squared, the results indicate that $91.4 \%$ of the variance in average liquidity ratio in local currency ALRLC, $73.2 \%$ of the variance in average liquidity ratio in foreign currency ALRFC, $90.8 \%$ of the variance in the proportion of securities to total assets S/A, and 92.7\% of the variance in the proportion of deposits to total assets D/A can be explained by the change in financial inclusion indicators.

If we now turn to the coefficient values of financial inclusion indicators, we can notice that they have low values which were found insignificant. This can be interpreted by the multicollinearity condition mentioned before i.e. that the independent variables are significantly correlated. Moreover, the coefficients of the independent variables vary between negative and positive values indicating that some of them have a positive effect on liquidity measures, while the others affect liquidity negatively.

Together these results can be used to accept the second hypothesis of this study i.e. financial inclusion has an impact on the Egyptian banks' liquidity.

\section{Discussion and Conclusion}

This study was set out with the aim of assessing whether the profitability and liquidity levels of Egyptian banks are affected by the execution of the financial inclusion plan. In order to reach this aim, the study used a set of data about Egyptian banks for the period from 2012 till September 2018 issued by the Central Bank of Egypt CBE.

By conducting correlation analysis, most of financial inclusion indicators were found to be significantly positively correlated with Egyptian banks' profitability measures. This indicates that financial inclusion has a positive association with the Egyptian banks' profitability. Another important finding that was reached by conducting correlation analysis is that most of financial inclusion indicators such as number of branches, number of ATMs, and number of points of sale are significantly negatively correlated to Egyptian banks' liquidity measures. This suggests the existence of negative association between financial inclusion and Egyptian banks' liquidity levels. 
As a second step in the statistical analysis, regression analysis was performed and led to a number of considerable results; the return on average assets and on average equity models showed significant results which indicates that the financial inclusion measures are able to account for a significant amount of the variance in the Egyptian banks' profitability. Surprisingly, the net interest margin model did not show a significant result indicating that financial inclusion indicators are not able to interpret a significant amount of variance in the Egyptian banks' net interest margin.

On the other hand, all of the models which were intended to analyze the effect of financial inclusion measures on the Egyptian banks' liquidity showed significant results which suggests that a significant amount of variance in the Egyptian banks' liquidity levels can be accounted for by the variance in financial inclusion measures.

This study produced results which corroborate the findings of a great deal of the previous work in this field. A number of relevant studies tied the expansion of ATM networks with the improvement in the banks' profitability (Humphrey, 1994; Jegede, 2014; Akhisar et. al., 2015; Shihadeh et. al., 2018). Increasing both the number of ATMs and the number of services they cover can be considered as new channels to deliver services to customers especially where it is difficult for a bank to open a branch. These new channels can encourage customers to open accounts in banks and to use bank services more frequently. In addition to that, the expansion in the ATM networks enables customers to obtain bank services anytime at lower costs which encourage them to use bank services more often and eventually result in improving the banks' ability to promote their services, earn more profits, and enhance their ability to lend customers.

In contrast to earlier findings which concluded that expanding the issuance of credit cards will increase the speed and reliability of banks' services, improve the efficiency of banks' operations, and -as a result- improve banks' profitability (Alfonse \& Florence, 2012; Muiruri \& Ngari, 2014), this study found that the effect of the number of credit cards issued by Egyptian banks on the profitability of Egyptian banks was insignificant. This finding agree with that of (Shihadeh et. al., 2018) in which the effect of the issued number of credit cards on banks' performance indicators was found insignificant, this result can be due to the usage of the number of issued credit cards and may be different if the number of used credit cards is employed instead.

As for the effect of financial inclusion on Egyptian banks' liquidity, in accordance with the present results, previous studies have demonstrated that financial inclusion will increase the stability of deposit and loan basis which will result in lower liquidity risk in the financial sector (Hannig\& Jansen ,2010; Prasad ,2010; Morgan \& Pontines ,2014), this is because increased lending to smaller firms and households results in a greater degree of diversification of the base of assets of banks which tend to reduce the overall degree of liquidity risk. However, the findings of the current study do not support those of Khan (2011) which concluded that as banks expand their pool of borrowers, they may find themselves obliged to sacrifice some lending standards, thus increasing the risk of default which could weaken the overall effectiveness of regulations and increase the degree of liquidity risk banks 
are prone to.

A possible explanation for these results may be that Egypt suffers from high levels of financial exclusion where only about $33 \%$ of its population had bank accounts in 2017 (Alexbank, 2017) and it is still in an early stage in the application of financial inclusion plan. In addition to that, Egypt is considered a cash-based economy i.e., most of its financial activities are performed by cash transactions. As a result, it is still early to reach general conclusions about the effect of financial inclusion on Egyptian banks' profitability and liquidity.

Another possible explanation for the results of this study is that the available data employed to test the study hypotheses starts from 2012, which is the start year of Egypt engaging in financial inclusion activities and becoming a member in the International Alliance for Financial Inclusion (AFI) which includes 95 developing countries exchanging technical and practical experiences in the field of financial inclusion. With this small sample size (2012 till September 2018), caution must be applied as the findings might differ if a larger sample size is used.

The combination of the above findings provides some support for the notion that banks should take several measures to enhance the development and achievement of financial inclusion by which they can make more profits, mitigate the degree of liquidity risk they are prone to, and improve their overall financial performance; these efforts will have a reflection on improving macro-economic variables such as decreasing unemployment levels and alleviating poverty which will result in improving Egypt's economic stability and development.

There is abundant room for further research efforts in determining the effect of financial inclusion on banks' performance. In future investigations, it might be possible to employ other measures of banks' profitability and liquidity or combining them with other measures of banks performance indicators such as their stock prices. It is also possible to encompass other indicators of financial inclusion, or to expand the research period in order to reach more accurate results, or using data of individual banks instead of aggregate data. Future studies on the current topic can also be carried out as comparative studies among Egypt and other countries in the MENA region or between developed countries which went some way in financial inclusion implementation and less-developed ones.

\section{References}

Abifarin, O., \& Bello, S. A. (2015). Cooperative Bank as an Effective Financial Inclusion Strategy in Nigeria. Journal of Law, Policy \& Globalization, 44, 5.

Akhisar, İ., Tunay, K. B., \& Tunay, N. (2015). The effects of innovations on bank performance: The case of electronic banking services. Procedia-Social and Behavioral Sciences, 195, 369-375. https://doi.org/10.1016/j.sbspro.2015.06.336

Alex Bank. (2017, December). Financial Inclusion in Egypt. Retrieved from https://www.alexbank.com/Cms_Data/Contents/AlexBank/Media/Publication/FlashNote/fina 
ncialinc.pdf

Alfonse, O. A., \& Florence, M. S. (2012). Credit cards and performance of commercial banks portfolio in Kenya. International Journal of Arts and Commerce, 1(6), 167-173.

Arif, A., \& Nauman, A. A. (2012). Liquidity risk and performance of banking system. Journal of Financial Regulation and Compliance, 20(2), 182-195. https://doi.org/10.1108/13581981211218342

Beck, T., \& Demirguc-Kunt, A. (2006). Small and medium-size enterprises: Access to finance as a growth constraint. Journal of Banking \& Finance, 30(11), 2931-2943. https://doi.org/10.1016/j.jbankfin.2006.05.009

Beck, T., Senbet, L., \& Simbanegavi, W. (2014). Financial inclusion and innovation in Africa: An overview. Journal of African Economies, 24(suppl_1), i3-i11. https://doi.org/10.1093/jae/eju031

Ben, N. S. (2014). Access to finance for small and medium-sized enterprises in the MENAP and CCA regions. International Monetary Fund.

Bruhn, M., \& Love, I. (2014). The real impact of improved access to finance: Evidence from Mexico. The Journal of Finance, 69(3), 1347-1376. https://doi.org/10.1111/jofi.12091

Central Bank of Egypt CBE. (2015). Financial and monetary sector 226.xlsx. Retrieved from http://www.cbe.org.eg/economic research/publications

Central Bank of Egypt CBE. (2017). Financial and monetary sector 248.xlsx. Retrieved from www.cbe.org.eg/economic research/publications

Central Bank of Egypt CBE. (2018a). Financial and monetary sector 258.xlsx. Retrieved from http://www.cbe.org.eg/economic research/publications

Central Bank of Egypt CBE. (2018b). Financial and monetary sector 260.xlsx. Retrieved from http://www.cbe.org.eg/economic research/publications

Central Bank of Egypt CBE. (2018c). Financial and monetary sector 261.xlsx. Retrieved from http://www.cbe.org.eg/economic research/publications

Chikalipah, S. (2017). What determines financial inclusion in Sub-Saharan Africa? African Journal of Economic and Management Studies, 8(1), 8-18. https://doi.org/10.1108/AJEMS-01-2016-0007

Consultative Group to Assist the Poor, CGAP. (2010). Financial access. The World Bank Group.

EMNES Studies. (2010, March). Financial development and inclusion in Egypt, Jordan, Morocco, and Tunisia, no 4.

Frame, W. S., \& White, L. J. (2014). Technological change, financial innovation, and diffusion in banking. The Oxford Handbook of Banking, 271. https://doi.org/10.1093/oxfordhb/9780199688500.013.0011 


\section{MInstitute ${ }^{\text {Macrothink }}$}

International Finance and Banking ISSN 2374-2089 2020, Vol. 7, No. 1

Fungáčová, Z., \& Weill, L. (2015). Understanding financial inclusion in China. China Economic Review, 34, 196-206. https://doi.org/10.1016/j.chieco.2014.12.004

Han, R., \& Melecky, M. (2013). Financial inclusion for financial stability: access to bank deposits and the growth of deposits in the global financial crisis. The World Bank. https://doi.org/10.1596/1813-9450-6577

Hannig, A., \& Jansen, S. (2010). Financial inclusion and financial stability: Current policy issues. Asian Development banking Institute. ADBI Working Paper Series. https://doi.org/10.2139/ssrn.1729122

Honohan, P. (2008). Cross-country variation in household access to financial services. Journal of Banking \& Finance, 32(11), 2493-2500. https://doi.org/10.1016/j.jbankfin.2008.05.004

Humphrey, D. B. (1994). Delivering deposits services: ATM s versus branches. Economic Quarterly, Federal Reserve Bank of Richmond, 80, 59-81. Retrieved from https://ssrn.com/abstract $=2125393$

Ifeakachukwu, N. P., \& Olasunkanmi, O. I. (2013). The impact of banks loan to SMEs on manufacturing output in Nigeria. Journal of Social and Development Sciences, 4(5), 212-217. https://doi.org/10.22610/jsds.v4i5.754

Jegede, C. A. (2014). Effects of automated teller machine on the performance of Nigerian banks. American Journal of Applied Mathematics and Statistics, 2(1), 40-46. https://doi.org/10.12691/ajams-2-1-7

Khan, H. R. (2011). Financial inclusion and financial stability: Are they two sides of the same coin. Speech at BANCON.

Kumar, N. (2013). Financial inclusion and its determinants: evidence from India. Journal of Financial Economic Policy, 5(1), 4-19. https://doi.org/10.1108/17576381311317754

Monyoncho, L. N. A. (2015). Relationship between Banking Technologies and Financial Performance of Commercial Banks in Kenya. International Journal of Economics, Commerce and Management, 3(2), 748-815.

Morgan, P., \& Pontines, V. (2014). Financial stability and financial inclusion. https://doi.org/10.2139/ssrn.2464018

Muiruri, J. K., \& Ngari, J. M. (2014). Effects of financial innovations on the financial performance of commercial banks in Kenya. International Journal of Humanities and Social Science, 4(7), 51-57.

Prasad, E. S. (2010). Financial sector regulation and reforms in emerging markets: An overview (No. w16428). National Bureau of Economic Research. https://doi.org/10.3386/w16428

Render, B. J. R., Hanna, M., \& Hale, T. (2017). Quantitative analysis for management (13th ed.). Pearson Education, India. 


\section{Macrothink}

Rose, P. S., \& Hudgins, S. C. (2005). Bank management \& financial services. McGraw-Hill.

Sansone, M., \& Formisano, V. (2016). Marketing Innovation and Key Performance Indicator in Banking. International Journal of Marketing Studies, 8(1), 44. https://doi.org/10.5539/ijms.v8n1p44

Shankar, S. (2013). Financial Inclusion in India: Do Microfinance Institutions Address Access Barriers. ACRN Journal of Entrepreneurship Perspectives, 2(1), 60-74.

Shihadeh, F. H., Hannon, A., Guan, J., Haq, I. U., \& Wang, X. (2018). Does Financial Inclusion Improve the Banks' Performance? Evidence from Jordan. In Global Tensions in Financial Markets (pp. 117-138). Emerald Publishing Limited. https://doi.org/10.1108/S0196-382120170000034005

Swamy, V. (2014). Financial inclusion, gender dimension, and economic impact on poor households. World Development, 56, 1-15. https://doi.org/10.1016/j.worlddev.2013.10.019

World Bank. (2010). Creating stability and enhancing access: helping develop Egypt's financial sector, IBRD results. Washington, DC: World Bank Group.

\section{Copyright Disclaimer}

Copyright for this article is retained by the author(s), with first publication rights granted to the journal.

This is an open-access article distributed under the terms and conditions of the Creative Commons Attribution license (http://creativecommons.org/licenses/by/4.0/). 